\title{
PRESTIGE AND NATIONAL IDENTITY AS PREDICTORS OF FOOD PRODUCTS PURCHASE
}

\author{
Srđan Šapić1, Srđan Furtula ${ }^{2}$, Danijela Durkalić ${ }^{3}$ \\ *Corresponding authorE-mail: danijela.durkalic@kg.ac.rs
}

\begin{abstract}
A R T I C LE I N F O
A B S T R A C T

Original Article

In modern living conditions, consumers have access

Received: 02 May 2018

to a greater offer of food products than ever before. In

Accepted: 15 June 2018 addition to local food products, the growth of foreign food products is noticeable, which significantly intensifies doi:10.5937/ekoPolj1802643S

UDC 323.1:338.439 competition in this sector. The paper analyzes whether and how national identity and prestige affect the assessment of local food products and whether this assessment affects

Keywords:

prestige, national identity, country of origin, product evaluation, domestic brand readiness to buy them. The research objective is to show whether national identity influences the purchase of local food products among consumers in Serbia, and whether prestige is important for the purchase process, as is the case with other product categories. The main research JEL:Z32, Z33 results indicate that the prestige factor has an impact on the assessment of both local and foreign food products, while the national identity factor has an impact only on local food product assessment. Also, research results indicate that food product assessment has an impact on the purchase of both local and foreign food products.
\end{abstract}

(C) 2018 EA. All rights reserved.

\section{Introduction}

Consumers facing varying product offer from different countries of origin often prefer products from their own country (Verlegh and Steenkamp, 1999, Verlegh et al., 2007). Numerous studies examine the relationship between the product country of origin and national identity, which results in emotional attachment to home country products (Netemeier, 1991; Klein, 1998, 2002). In this regard, nationalism and patriotism, as well as the concept of consumer ethnocentrism emerge. The relevant literature makes a distinction between the concept of nationalism and the concept of patriotism. Generally, both terms relate to positive identification with a particular nation. However, nationalism

1 Srđan Šapić, Associate Professor, Faculty of Economics, University in Kragujevac, Đure Pucara Starog 3,+381641266926, ssapic@kg.ac.rs, https://orcid.org/0000-0002-3855-1540

2 Srđan Furtula, Associate Professor, Faculty of Economics, University in Kragujevac, Đure Pucara Starog 3,+381692349031, furtulas@kg.ac.rs, https://orcid.org/0000-0002-0692-6539

3 Danijela Durkalić, Teaching assisstant, Faculty of Hotel Management and Tourism, University in Kragujevac, Vojvodjanska 5A, 36210 Vrnjačka Banja, Serbia, +381645806599, danijela.durkalic@kg.ac.rs, https://orcid.org/0000-0001-8605-8614 
implies superiority and dominance of one nation over others. On the other hand, patriotism, as a feeling of love for one's own country, does not imply national domination (van der Toorn, Nail, Liviatan \& Jost, 2014). Patriotism is based on emotional attachment to one's own people, nationalism discriminates against members of other nations. Ethnocentrism is the attitude in which one's own group is in the center of everything, while all others are judged and ranked in relation to it (Shankarmahesh, 2006). The main consequence of consumer ethnocentrism is the consumer intention to buy local products, i.e. their unwillingness to purchase foreign products. On the other hand, there are many reasons for buying foreign products. By purchasing foreign products, consumers improve their status as well as their image in society (Strizhakova et al, 2008).

\section{Literature Review}

\section{Prestige}

There are many reasons why consumers prefer global to local brands. One of the reasons may be the higher perceived prestige of global brands (Kapferer, 1997). Holt et al. (2004) point out that one of the major associations related to global brands is their prestige. Global brands are, generally speaking, less accessible and more expensive than local alternatives, which can contribute to the creation of their prestigious reputation (Batra et al., 2000). Consumers themselves buy and use such products to improve their status as well as social image (Strizhakova et al, 2008). Some consumers, in addition, buy global brands to enhance their own image in terms of cosmopolitanism, sophistication, and modernism (Friedman, 1990). According to Ergin \& Akbai (2010), the concept of brand prestige can mean different things to different consumers or consumers have different perceptions of prestige for the same brand. As Wong and Zhou (2005) point out, the perception of brand prestige has a greater impact on a purchasing intention when a product is in a category of high social visibility. The aim of this paper is to investigate whether this is the case with the purchase of food products.

Social prestige is reflected in consumer assessment of increased self-esteem and social status due to the possession and use of products belonging to the category of global brands (Steenkamp, Batra, \& Alden, 2003). Numerous authors point out that one of the main consumer motivators to purchase global brands is the desire to improve their own status in society (Holt, 2002; Thompson \& Tambyah, 1999). Many researchers define brand prestige as a subjective judgement on a relatively high status of a brandrelated product (Stongkamp, Batra, \& Alden, 2003; Truong, McColl, \& Kitchen, 2009; Monga \& John, 2010). This judgment is often accompanied by emotional reactions (Bagozzi, Gopinath, \& Nier, 1999). Past studies provide empirical evidence to prove it (Holt, Quelch, \& Taylor, 2004; Nan \& Belk, 2004; Ger, 1999). This connection is especially emphasized in developing countries as consumers perceive brands from Western countries as symbols of prestige and status (Coulter et al., 2003; Batra et al., 2000). The reason for this is that consumers find a symbolic connection between global brands and the most developed countries from which these brands come, and that by purchasing these brands they want to acquire the lifestyle of consumers from these 
parts of the world (Özsomer, 2012; Alden, Steenkamp, Batra 2006). In addition, by purchasing global brands, consumers want to get products that are used for the so-called conspicuous consumption. This is particularly pronounced in developing countries in which consumers tend to use global brand ownership and/or consumption to increase their social status and enhance identity and prestige (Batra et al., 2000). On the other hand, consumers in certain situations (when they are authentic) can also connect local brands with a high level of prestige. Some studies prove this assertion (Özsomer, 2012; Steenkamp, Batra, \& Alden, 2003). Some studies on a target group of consumers living in developed Western countries point to preferences for local products (Balabanis, Diamantopoulos (2004)), while respondents in developing countries and emerging economies prefer foreign branded products (Marcoux et al., 1997, 9, Batra et al., 2000). Consumers consider branding or foreign products as a symbol of prestige, following trends and the latest lifestyles to improve their image in society (Zhou et al., 2008). These ideas are used in the paper to formulate the variable of prestige.

Steenkamp at al. (2003) suggest that brand prestige affects purchasing intentions, i.e. there is a positive correlation between prestige and purchasing intent. Yagci (2001) finds that brand image is an important factor that not only has an impact on the quality perception and consumer attitude towards products, but, at the same time, significantly influences consumer product purchase as a strong predictor of consumer purchasing intentions. On the other hand, Eze, Yee and Vamala (2012) discover the opposite. In their opinion, consumers do not form their product purchasing intentions based on brand image, which indicates that the brand does not have a priority impact on purchasing intentions. Shah et al. (2012) study how the branding concept influences consumer purchasing intentions. According to them, the main brand image consists of two elements, namely brand recognition and brand preferences, and both elements affect purchasing intentions.

Food product consumers, in addition to economic reasons and social belonging, pay special attention to quality when giving priority to local over foreign food products (Lusk et al., 2006). The country of origin labels on food products can influence the quality perception. In particular, the local country indication refers to the quality of traditional production methods and induces perceptions of trust and self-confidence (Von Alvensleben, Gertken, 1993).

The aim of this study is to analyze whether the image is important in the purchase of food products, i.e. if purchase be considered prestigious. Bearing in mind the abovestated theoretical claims and results of previous empirical research, the following research hypotheses are defined:

H1: Prestige has a positive and statistically significant influence on the assessment of local food products.

$\mathrm{H} 2$ : Prestige has a positive and statistically significant influence on the assessment of foreign food products. 


\section{National identity}

The significance of an individual's national affiliation, as well as subjective significance of the inner connection with the nation, is a national identity (Blank \& Schmidt, 2003). Nakata and Sivakumar (2001) define national identity as a set of thinking, feeling, and action patterns, derived from conventional and accepted conventions and values of a particular society. It is a degree in which individuals identify themselves with their own nation and have a positive sense of belonging to it (Tajfel, Turner 1986). The strength of national identity is operationalized as a subjective and multiple construction consisting of: individual's perception of common origin, feelings of common socio-cultural experience, interactions, values, and norms, as well as feelings of belonging, pride, and commitment to a particular national group (Cleveland, Rojas-Mendez, Laroche, \& Papadopoulos, 2016).

There are studies that focus on the effect of differences in the strength of individuals' national identity on the assessment of local and foreign products. Verlegh (2007) proves that national identity has an impact on the assessment of quality and desire and readiness to purchase different categories of local products, including food products, while the negative impact of identity on readiness to purchase foreign products is revealed only in two of eight product categories. Zeugner-Roth, Žabkar, \& Diamantopoulos (2015) conduct a study stating that national identity has a stronger positive impact on the rating and readiness to purchase local products than ethnocentrism, while in foreign products national identity affects positively the rating, but not readiness to buy.

The country of origin concept, covered by the definition of a "geographical indication", provides the basis for identity, diversity, tradition, and authenticity - individual and social, local, and national (Almli et al., 2011). Food can be used as a metaphor for diversity and to promote cultural superiority. The identity of the national cuisine has to do with geographical boundaries and regional identities (van Ittersum, 1999). Some researchers assume that territorial or regional identity is more shaped by their typical food than language or dialect (Petrini, 2011; Parasecoli, 2005).

Public campaigns focus on the danger of losing national identity and try to provoke national feelings, but also to evoke the feelings of consumers' duty towards local economy (Parasecoli, 2005). Normative reasons for buying local food products play a major role where local agribusiness is threatened by imports. In addition, information on the food country of origin may be a general quality indicator when other information is not available. Basically, it is the quality perceived by the consumer, rather than the "objective" quality that influences the consumers' decision-making process (Knight et al., 2007; Saenz-Navajast et al., 2014). Objective quality is defined by the total number of product attributes including its origin, ingredients, and all attributes that can be detected by food analysis. Subjective quality is defined by personal quality evaluation, so each consumer has their own quality definition and requirements. The most important aspects of food quality are certainly related to taste and safety, including production processes and product performance (Bachl, 2011; Ortega et al., 2014). In 
this paper, the subjective quality of food products is examined, among other things, under the influence of national identity.

Parrot (2002) makes a distinction between northern and southern food culture. Northern food culture is characterized by "efficient" production, while southern food culture, which sees food consumption as hedonism (Gomez and Torelli, 2015), is characterized by tradition and craft production, and the connection of healthy eating with typical and local products (Balestrieri i Brunori, 2003).

Buying food products, among other things, depends on the national context in which consumers live. In Serbia, according to one study, consumers are motivated by quality when buying local food, but also prefer local food regardless of quality, due to moral beliefs about the support to the local food economy (Bosbach et al., 2015).

The aim of this paper is to examine whether consumer national identity is expressed in Serbia and whether it has an impact on food product assessment and purchase. Based on the theoretical statements, the results of the previous research, and the goals set in this paper, the following hypotheses can be defined:

H3: National identity has a positive and statistically significant impact on the assessment of local food products.

H4: National identity has a positive and statistically significant impact on the assessment of foreign food products.

\section{Product assessment based on the country of origin}

The effects of the country of origin (COO) mean that certain consumers show positive or negative tendency to purchase different products, depending on the country of origin with which they associate them (Magnusson et al., 2011; Josiassen \& Harzing, 2008; Verlegh \& Steenkamp, 1999). Many authors conclude that the country of origin of products and services has an impact on product assessment and purchasing behavior of consumers (Pharr, 2005; Sharma, 2011; Verlegh \& Steenkamp, 1999; Peterson \& Jolibert, 1995). The product country of origin influences consumers' product assessment, because they use all available product information when evaluating it (Kaynak \& Kara, 2002). In this study, the effect of the food product country of origin is considered through product evaluation and the impact of evaluation on consumers' readiness to buy products.

Hong \& Wyer (1989) indicate that the country of origin serves as a very important basis for consumers' product and service assessment. Many authors consider the product country of origin and its image to positively or negatively affect the assessment of products coming from these countries (Costa et al., 2016; Chen et al., 2014; Laroche, et al., 2005). According to Laroche et al. (2005), product assessment refers to a set of attitudes the consumer has about the product, which is expressed by the liking, satisfaction of having a product, and the desire to buy it. When assessing products and services, consumers analyze certain internal characteristics that are directly related to 
the product and are physically tangible (design, shape, color), as well as external ones, which are less tangible (price, guarantee, brand, name of the manufacturer, and product country of origin) (Verlegh \& Steenkamp, 1999; Manrai et al., 1998). The second group of characteristics gets important when consumers cannot completely objectively evaluate the product.

Readiness to purchase a product differs from the consumer intention to make a purchase, in terms of the necessary expenditure to actually buy a product or service (Koschate-Fischer et al., 2012). Sun and Morwitz 2010) point out that intentions are time-varying and that they do not have to accurately predict the real behavior of consumers. It is therefore important to examine whether consumer intentions will be realized. The purchase intention arises from the product evaluation, i.e. benefits that must be greater than the product cost. This correlation of product evaluation and readiness for purchase is described in numerous studies (Zeugner-Roth et al., 2015; Josiassen, 2011; Klein et al, 1998).

Koubaa (2008) finds that the image of the product country of origin is of great influence on the consumer perception about the product image. Similarly, according to Hsieh et al. (2004), when consumers have a favorable perception of the brand's country of origin, they also appreciate brands from that particular country, which, in turn, improves the brand image, and vice versa, the negative image of the country of origin in the eyes of consumers prevents them from buying brands from that country. It is found that the image of the country of origin directly affects the purchasing intention of consumers (Josiassen \& Assaf, 2010; Wang \& Yang, 2008). However, other researchers such as Diamantopoulos et al. (2011) prove that the image of the country of origin indirectly affects consumers' intentions to buy foreign products through the brand image. Most COO literature deals with the purchase of durable but not food products. Few studies examine the influence of the country of origin on the propensity to purchase local food products (Eriksson, 2011; Ellison et al., 2010; Knight, 2007; von Alvensleben et al., 1993). The aim of this paper is to fill this research gap.

The paper examines the impact of product assessment on the consumers' readiness to purchase local and foreign food products as part of the overall effects of the country of origin through the following hypotheses:

H5: Positive assessment of local food products by consumers positively influences their purchase of local food products.

H6: Positive assessment of foreign food products by consumers positively influences their purchase of foreign food products.

\section{Materials and methods}

Bearing in mind the analyzed variables and hypotheses, a conceptual research model can be defined. The model (Figure 1) shows that variables related to food product prestige and national identity influence the assessment of these products, and that food product assessment affects the purchase of this product type. 
Figure 1. Conceptual research model

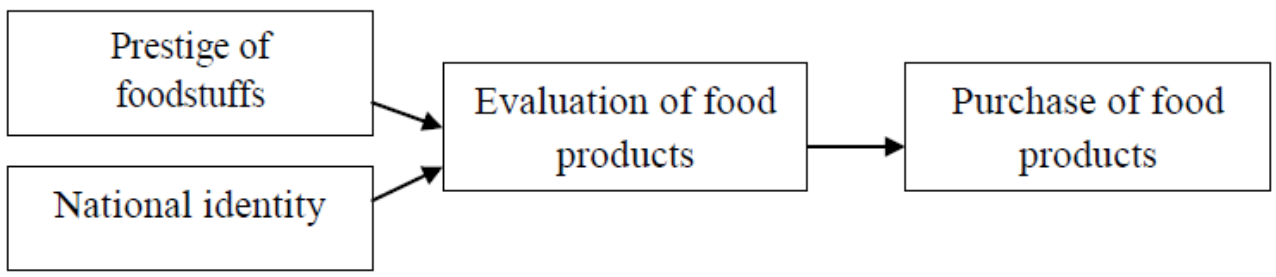

In order to analyze the previously established links, a survey covered the territory of Šmadija. The survey was conducted in February 2018, with a total of 146 valid questionnaires collected. In the structure of the sample, most of the respondents were women (53.4\%). In addition, the largest percentage of respondents were members of younger and middle-aged generations (close to $80 \%$ ), with secondary education $(48.5 \%)$. The data was obtained by distributing the questionnaire personally, with the respondents evaluating the degree of their agreement with the stated items on the sevenpoint Likert scale (1 - I strongly disagree, 7 - I strongly agree).

Statistical data processing and analysis were performed using Microsoft Excel and SPSS (Statistical Package for Social Sciences, 21.0) software packages. Of statistical analyses, descriptive statistics analysis, exploratory factor analysis, simple and multiple linear regression were used.

\section{Results}

In order to group the questionnaire statements into factors, exploratory factor analysis is performed, giving three factors, referring to the observed variables in the research model. The value of the Kronbach alpha coefficient (Table 1) is significantly higher for all factors than the recommended value of 0.7 (Nunnally, 1978), which shows that the factors have a very good internal consistency. Indicators that must be considered when assessing the justification for exploratory factor analysis are Bartlett's test of sphericity and Kaiser-Meyer Olkin's (KMO) sample adequacy indicator. The KMO indicator value in this study is 0.799 , while Bartlett's test of sphericity has a statistically significant value (Sig. $=0.000)$, which indicates that the use of factor analysis is justified. The total percentage of variance explained by these three factors is $79.63 \%$.

Table 1. Results of exploratory factor analysis

\begin{tabular}{|l|c|}
\hline Items & $\boldsymbol{\alpha}$ \\
\hline Prestige of local food products & 0.930 \\
\hline Prestige of foreign food products & 0.915 \\
\hline National identity & 0.868 \\
\hline Bartlett's test of sphericity & Sig. $=0,000$ \\
\hline KMO & 0,799 \\
\hline
\end{tabular}

Source: Authors' calculations 
The results of descriptive statistics (Table 2) show that the respondents gave the highest rating to the national identity $(\mathrm{AS}=5,739, \mathrm{SD}=1,214)$ variable. On the other hand, variables Purchase of foreign food products $(\mathrm{AS}=3.736, \mathrm{SD}=1.665)$ and Prestige of local food products $(\mathrm{AS}=3.827, \mathrm{SD}=1.590)$ had the lowest rating.

Table 2. Results of descriptive statistics analysis

\begin{tabular}{|l|c|c|}
\hline Items & AS & SD \\
\hline Prestige of local food products & 3.827 & 1.590 \\
\hline Prestige of foreign food products & 4.227 & 1.644 \\
\hline National identity & 5.739 & 1.214 \\
\hline Assessment of local food products & 4.646 & 1.385 \\
\hline Assessment of foreign food products & 4.424 & 1.346 \\
\hline Purchase of local food products & 5.061 & 1.425 \\
\hline Purchase of foreign food products & 3.736 & 1.665 \\
\hline
\end{tabular}

Source: Authors' calculations

In order to test the hypotheses, two multiple and two two-dimensional regression analyses were used. The results of these analyses are presented in Tables 3, 4, 5, and 6.

The results of multiple linear regression shown in Table 3 indicate that the prestige of local products $(\beta=0.243$, Sig. $=0.002)$ and national identity $(\beta=0.364$ Sig. $=0.000)$ have a positive and statistically significant influence on the assessment of local food products. This confirmed the hypotheses $\mathrm{H1}$ and $\mathrm{H3}$.

Table 3. Results of multiple regression (dependent variable - Assessment of local food products)

\begin{tabular}{|c|l|c|c|c|c|}
\hline Hypothesis & Variable & $\boldsymbol{\beta}$ & $\mathbf{t}$ & Sig. & VIF \\
\hline H1 & Prestige of local food products & 0.243 & 3.235 & 0.002 & 1.035 \\
\hline H3 & National identity & 0.364 & 4.852 & 0.000 & 1.032 \\
\hline
\end{tabular}

Source: Authors' calculations

When it comes to foreign products, it can be noticed that the prestige of foreign food products has a positive and statistically significant impact on assessment $(\beta=0.331$, Sig. $=0.000)$, while national identity has no statistically significant impact on the assessment of this product type $(\beta=0.016$, Sig. $=0.842)$. This confirms hypothesis H2, but not the H4 hypothesis.

Table 4. Results of multiple regression (dependent variable - Assessment of foreign food products)

\begin{tabular}{|c|l|c|c|c|c|}
\hline Hypothesis & Variable & $\boldsymbol{\beta}$ & $\mathbf{t}$ & Sig. & VIF \\
\hline H2 & Prestige of foreign food products & 0.331 & 4.192 & 0.000 & 1.002 \\
\hline H4 & National identity & 0.016 & 0.200 & 0.842 & 1.005 \\
\hline
\end{tabular}

Source: Authors' calculations 
It should be pointed out that multicollinearity is not a problem in the presented analyses, since the variance inflation factor (VIF) is lower than the recommended value of 5, in the case of the impact of both factors on the assessment of both local and foreign food products (Field, 2000).

Table 5. Results of linear regression (dependent variable - Purchase of local food products

\begin{tabular}{|c|l|c|c|c|}
\hline Hypothesis & Variable & $\boldsymbol{\beta}$ & $\mathbf{t}$ & Sig. \\
\hline H5 & Assessment of local food products & 0.477 & 5.997 & 0.000 \\
\hline
\end{tabular}

Source: Authors' calculations

Study of the impact of food product assessment on their purchase was done through a simple regression analysis (Tables 5 and 6). The above analysis shows that, in the case of local food products, consumers' assessment has a positive and statistically significant influence on the purchase of these products $(\beta=0,477$, Sig. $=0,000)$. This confirms the $\mathrm{H5}$ hypothesis.

Table 6. Results of linear regression (dependent variable - Purchase of foreign food products)

\begin{tabular}{|c|l|c|c|c|}
\hline Hypothesis & Variable & $\boldsymbol{\beta}$ & $\mathbf{t}$ & Sig. \\
\hline H6 & Assessment of foreign food products & 0.491 & 6.768 & 0.000 \\
\hline
\end{tabular}

Source: Authors' calculations

When it comes to foreign food products, product assessment also has a strong, positive, and statistically significant influence on the purchase of food products $(\beta=0,491$, Sig. $=0,000)$. This confirms the H6 hypothesis.

\section{Conclusion}

The paper analyzes the influence of prestige and national identity on the assessment and purchase of food products. The results show that the respondents gave the highest rating to the variables related to national identity ( $\mathrm{AS}=5,739)$. On the other hand, variable Purchase of foreign food products $(\mathrm{AS}=3.736)$ had the lowest rating, which supports the aforementioned. The results of the analysis also show that the prestige of local products and national identity have a positive and statistically significant impact on the assessment of local food products, which is consistent with the results of previous researchers like Yagci, (2001); Verlegh, (2007) and Zeugner-Roth et al. (2015). This confirmed the hypotheses H1 and H3. The influence of nationalism on quality assessment of local food products in Serbia was also proven in the study by Bosbach et al. (2015). The analyses carried out in this paper point to the influence of prestige but not of national identity on the assessment of foreign food products. This confirmed H2 hypothesis, but not the H4 hypothesis, which can be, among other things, explained by the results of previous studies, stating that openness towards other cultures and ethnocentrism in Serbia are not in contradiction in the assessment of food products. One of the conclusions drawn from the conducted analysis in this 
paper is that consumers' assessment has a positive, statistically significant impact on the purchase of both local and foreign food products, thus confirming the H5 and H6 hypotheses. The results are in line with the research carried out in Serbia by Bosbach et al. (2015), which indicates the existence of a positive, statistically significant impact of quality assessment on the purchase of food products. The conducted research has certain limitations. One of them is that it was not conducted on the whole territory of Serbia, which would increase the representativeness of the sample and generalize the conclusion. Another limitation is that the largest percentage of respondents belonged to youth and middle-aged groups, with secondary education. Also, the analysis did not include other factors that influence product perception and purchase, which could be the subject and objective of future research.

\section{Acknowledgements}

Paper is a part of research within the project no. III 46006 - Sustainable agriculture and rural development in the function of accomplishing strategic objectives of the Republic of Serbia in the Danube region, financed by the Ministry of Education, Science and Technological Development of the Republic of Serbia. Project period: 2011-2018.

\section{Conflict of interests}

The authors declare no conflict of interest.

\section{References}

1. Alden, D. L., Steenkamp, J-B. E.M., \& Batra, R. (1999). Brand Positioning Through Advertising in Asia, North America, and Europe: The Role of Global Consumer Culture. Journal of Marketing, 63 (January), 75-87.

2. Almli, V. L., Verbeke, W., Vanhonacker, F., Naes, T., \& Hersleth, M. (2011). General image and attribute perceptions of traditional food in six European countries. Food Quality and Preference, 22 (1), 129-138.

3. Bachl, T. (2011). Consumers' Choice '11, GfK Panel Services Deutschland und Bundesvereinigung der Deutschen Ernährungsindustrie e.V., BVE, anuga.

4. Bagozzi, R. P., Gopinath, M., \& Nyer, P. U. (1999). The role of emotions in marketing. Journal of the Academy of Marketing Science, 27(2), 184-206. http://dx.doi.org/10.1177/0092070399272005

5. Balabanis, G., \& Diamantopoulos, A. (2004). Domestic Country Bias, Country-of-Origin Effects, and Consumer Ethnocentrism: A Multidimensional Unfolding Approach. Journal of the Academy of Marketing Science, 32 (1), 80-95.

6. Balestrieri, G., \& Brunori, G. (2003), Consumers attitude towards some regional food products in Tuscany, paper presented at the RSA Conference "Reinventing Regions in the Global Economy" Pisa 12-15 April. 
7. Batra, R., Ramaswamy, V., Alden, D.L., Steenkamp, J-B EM., \& Ramachander, S. (2000). Effects of brand local/nonlocal origin on consumer attitudes in developing countries. Journal of Consumer Psychology, (9), 83-95.

8. Blank, T. \& Schmidt, P. (2003), "National Identity in a United Germany: Nationalism or Patriotism? An Empirical Test with Representative Data," Political Psychology, 24 (2), 289-312.

9. Bosbach M, Ornella Wanda Maietta O. \& W., \& Marquardt H. (2015), Domestic Food Purchase Bias: A Cross-Country Case Study of Germany, Italy and Serbia, CSEF - Centre for Studies in Economics and Finance DEPARTMENT OF ECONOMICS - UNIVERSITY OF NAPLES, 80126 NAPLES - ITALY

10. Chen, C. Y., Mathur, P., \& Maheswaran, D. (2014). The effects of countryrelated affect on product evaluations. Journal of Consumer Research, 41(4), 1033-1046.

11. Cleveland, M., Rojas-Mendez, J. I., Laroche, M., \& Papadopoulos, N. (2016). Identity, culture, dispositions and behavior: A cross-national examination of globalization and culture change. Journal Of Business Research, (3), 1090. doi:10.1016/j.jbusres.2015.08.025

12. Costa, C., Carneiro, J., \& Goldszmidt, R. (2016). A contingent approach to country-of-origin effects on foreign products evaluation: Interaction of facets of country image with product classes. International Business Review, 25 1066-1075. doi:10.1016/j.ibusrev.2016.01.003

13. Coulter, R. A., Price, L. L., \& Feick, L. (2003). Rethinking the origins of product involvement, involvement with branded products, and brand commitment: Women and cosmetics in postsocialist Central Europe. Journal of Consumer Research, 30, 151-169.

14. Diamantopoulos, A., Schlegelmilch, B., \& Palihawadana, D. (2011). The relationship between country-of-origin image and brand image as drivers of purchase intentions: A test of alternative perspectives. International Marketing Review, 28, 508-524.

15. Ellison B.D., Lusk J.L., \& Briggeman, B.C. (2010). Taxpayer beliefs about farm income and preferences for farm policy, Applied Economic Perspectives and Policy, 32 (2), 338- 354.

16. Ergin E. A., \& Akbay H. O. (2010). Consumers' Purchase Intentions for Foreign Products: An Empirical Research Study in Istanbul, Turkey. 2010 EABR \& ETLC Conference Proceedings Dublin, Ireland, 510-517.

17. Eriksson, C. (2011). Home bias in preferences and the political economics of agricultural protection, Review of Agricultural and Environmental Studies, 92, 5-23

18. Eze, U. C., Yee, K. P., \& Wamala, F. (2012). Analyzing the intention to purchase proton automobiles: Preliminary findings. Contemporary Management Research, 8, 267-274. 
19. Field, A. (2000). Discovering statistics using SPSS for Windows. Sage Publication: Thousand Oaks.

20. Friedman, J. (1990). Being in the world: globalization and localization. Theory, Culture and Society, (7), 311-328.

21. Ger, G. (1999). Localizing in the Global Village: Local Firms Competing in Global Markets. California Management Review, 41 (4), 64-83.

22. Gomez, P., \& Torelli, C.J (2015). It's not just numbers: Cultural identities influence how nutrition information influences the valuation of foods, Journal of Consumer Psychology, 23, 3, 404-415.

23. Holt, D. B. (2002). Why Do Brands Cause Trouble? A Dialectical Theory of Consumer Culture and Branding. Journal of Consumer Research, 29 (June), 70-90.

24. Holt, D. B., Quelch, J.A., \& Taylor, E.L. (2004). How Global Brands Compete. Harvard Business Review, 82 (September), 68-75.

25. Hong, S-T., \&. Wyer, R. S. Jr. (1989). Effects of Country-of-Origin and ProductAttribute Information on Product Evaluation: An Information Processing Perspective. Journal of Consumer Research, 16 (2), 175-187.

26. Hsieh, M. H., Pan, S. L., \& Setiono, R. (2004). Product-, corporate-, and country-image dimensions and purchase behavior: A multicountry analysis. Journal of the Academy of Marketing Science, 32, 251-270.

27. Josiassen, A. (2011). Consumer Disidentification and Its Effects on Domestic Product Purchases: An Empirical Investigation in the Netherlands. Journal of Marketing, 75 (March), 124-140.

28. Josiassen, A., \& Assaf, A. (2010). Country-of-origin contingencies: Their joint influence on consumer behaviour. Asia Pacific Journal of Marketing and Logistics, 22, 294-313.

29. Josiassen, A., \& Harzing, A.-W. (2008). Descending from the ivory tower: Reflections on the relevance and future of country of-origin research. European Management Review, 5(4), 264-270.

30. Kapferer, J-N. (1997). Strategic Brand Management, 2nd edn, Kogan Page: Dover, NH.

31. Kaynak, E., \& Kara, A. (2002). Consumer perceptions of foreign products: an analysis of product-country images and ethnocentrism. European Journal of Marketing, 36(7/8), 928-949.

32. Klein, J. G. (2002). Us versus Them, or Us versus Everyone? Delineating Consumer Aversion to Foreign Goods. Journal of International Business Studies, 33 (2), 345-363.

33. Klein, Jill G., Richard Ettenson, and Marlene D. Morris (1998), “The Animosity Model of Foreign Product Purchase: An Empirical Test in the People's Republic of China," Journal of Marketing, 62 (January), 89-100. 
34. Knight, J. G., Holdsworth, D. K., \& Mather, D. W. (2007). Country-of-origin and choice of food imports: An in-depth study of European distribution channel gatekeepers. Journal of International Business Studies, 38(1), 107-125.

35. Koschate-Fischer, N., Diamantopoulos, A., \& Oldenkotte, K. (2012). Are Consumers Really Willing to Pay More for a Favorable Country Image?? A Study of Country-of-Origin Effects on Willingness to Pay. Journal of International Marketing, 20(1), 19-41. doi:10.1509/jim.10.0140

36. Koubaa, Y. (2008). Country of origin, brand image perception, and brand image structure. Asia Pacific Journal of Marketing and Logistics, 20, 139-155.

37. Laroche, M., Papadopoulos, N., Heslop, L., \& Mourali, M. (2005). The influence of country image structure on consumer evaluations of foreign products. International Marketing Review, 22(1), 96-115.

38. Lusk, J.L., Brown J., Mark, T., Proseku, I., Thompson, R., \& Welsh, J. (2006). Consumer behavior, public policy, and country-of-origin labeling. Review of Agricultura Economics, 28(2), 284-292.

39. Magnusson, P., Westjohn, S., \& Zdravkovic, S. (2011). What? I thought Samsung was Japanese: accurate or not, perceived country of origin matters. International Marketing Review, 28(5), 454-472.

40. Manrai, L., Lascu, D.-N., \& Manrai, A. (1998). Interactive effects of country of origin and product category on product evaluations. International Business Review, 7, 591-615.

41. Marcoux, J. S., Filialtrault, P. and Che'ron, E. (1997) The Attitudes Underlying Preferences of Young Urban Educated Polish Consumers Towards Products Made in Western Countries. Journal of International Consumer Marketing, 9, 4, 5-29.

42. Monga, A. B. \& John, D. R. (2010). What makes brands elastic? The influence of brand concept and styles of thinking on brand extension evaluation. Journal of Marketing, 74(3), 80-92. http://dx.doi.org/10.1509/jmkg.74.3.80

43. Moritz Bosbach, Ornella Maietta and Hannah Marquardt, July 2015, Domestic Food Purchase Bias: A Cross-Country Case Study of Germany, Italy and Serbia, CSEF - Centre for Studies in Economics and Finance DEPARTMENT OF ECONOMICS - UNIVERSITY OF NAPLES, 80126 NAPLES - ITALY

44. Nakata, C., \& Sivakumar, K. (2001).Instituting the Marketing Concept in a Multinational Setting: The Role of National Culture. Journal Of The Academy Of Marketing Science, 29(3), 255-275.

45. Netemeyer, R. G., Durvasula, S., \& Lichtenstein, D. R. (1991). A CrossNational Assessment of the Reliability and Validity of the CETSCALE. Journal Of Marketing Research (JMR), 28(3), 320-327.

46. Nunnally, J.C. (1978), Introduction to Psychological Measurement, McGrawHill, New York, NY. 
47. Ortega, D. L., Wang, H. H., \& Olynk Widmar, N. J. (2014). Effects of Media headlines on Consumer Preferences for Food Safety, Quality and Environmental Attributes. Australian Journal of Agricultural and Resource Economics, 58, 1-13.

48. Özsomer, A. (2012). The Interplay Between Global and Local Brands: A Closer Look at Perceived Brand Globalness and Local Iconness. Journal of International Marketing, 20 (1), 71-94.

49. Parasecoli, F. (2005). Culinary cultures of Europe: Identity, diversity and dialogue. Strasbourg.

50. Parrot, N. (2002). Spatializing Quality: Regional Protection and the Alternative Geography of Food, European Urban and Regional Studies, 9 (3), 241-261.

51. Peterson, R.A., \& Jolibert, A.J.P. (1995). A meta-analysis of country-of-origin effects. Journal of International Business Studies, 26(4), 883-900.

52. Petrini, C. (2011). Terra Madre - Come non farci mangiare dal cibo. Giunti Edizioni. Slow Food Editore.

53. Pharr, J.M. (2005). Synthesizing country-of-origin research from the last decade: is the concept still salient in an era of global brands?. Journal of Marketing Theory and Practice, 13(4), 34-45.

54. Sáenz-Navajas M., Ballester J., Peyron D., \& Valentin, D. (2014). Extrinsic attributes responsible for red wine quality perception: A cross-cultural study between France and Spain, Food Quality and Preference, 5, 70-85.

55. Shah, S. S. H., Aziz, J., Raza, J. A., Waris, S., Ejaz, W., Fatima, M., \& Sherazi, S. K. (2012). The impact of brands on consumer purchase intentions. Asian Journal of Business Management, 4, 105-110.

56. Shankarmahesh, M. (2006). Consumer ethnocentrism: An integrative review of its antecedents and consequences. International Marketing Review, 23(2), 146-172. doi: 10.1108/02651330610660065

57. Sharma, P. (2011). Country of Origin Effects in Developed and Emerging Markets: Exploring the Contrasting Roles of Materialism and Value Consciousness. Journal of International Business Studies, 42 (2), 285-306.

58. Steenkamp, J. B., Batra, R., \& Alden, D. L. (2003). How perceived brand globalness creates brand value. J. Int. Bus.Stud., 34, 53-65. http://dx.doi. org/10.1057/palgrave.jibs.8400002

59. Strizhakova, Y., Coulter, R.A., \& Price, L. L. (2008). The Meanings of Branded Products: A Cross-National Scale Development and Meaning Assessment. International Journal of Research in Marketing, 25 (2), 82-93.

60. Sun, Baohong \& Vicki G. Morwitz (2010), "Stated Intentionsand Purchase Behavior: A Unified Model," International Journal of Research in Marketing, 27 (4), 356-66. 
61. Tajfel, H., \& Turner, J. C. (1986). The social identity theory of intergroup behavior. In S. Worchel \& W. G. Austin (Eds.), The psychology of intergroup relations, 7-24. Chicago: Nelson-Hall.

62. Thompson, C. J., \& Tambyah, S. K. (1999). Trying to Be Cosmopolitan. Journal of Consumer Research, 26 (3), 214-241.

63. Truong, Y., McColl, R., \&Kitchen, P. J. (2009). New luxury brand positioning and the emergence of masstige brands. Journal of Brand Management, 16(5), 375-382.

64. Van der Toorn, J., Nail, P. R., Liviatan, I., \& Jost, J. T. (2014). My country, right or wrong: Does activating system justification motivation eliminate the liberalconservative gap in patriotism? Journal of Experimental Social Psychology, 54, 50-60. doi: 10.1016/j.jesp.2014.04.003

65. Van Ittersum, K. (1999), Consumer Ethnocentrism and Regional Involvement as Antecedent of Consumers' Preference for Products of the Own region. In: EU-AIR III project "Food for the Consumer", 5, 1, 45-51.

66. Verlegh, P.W.J. (2007). Home Country Bias in Product Evaluation: The Complementary Roles of Economic and Socio-Psychological Motives. Journal of International Business Studies, 38 (3), 361-373.

67. Verlegh, P.W.J., \& Steenkamp, J.-B.E.M., (1999). A review and meta-analysis of country-of-origin research. Journal of Economic Psychology, 20 (5), 521-546.

68. Von Alvensleben, R. \& Gertken, D. (1993). Regionale Gütezeichen als Marketinginstrument bei Nahrungsmitteln, Agrarwirtschaft 42 (6), 247-251.

69. Wang, X., \& Yang, Z. (2008). Does country-of-origin matter in the relationship between brand personality and purchase intention in emerging economies? Evidence from China's auto industry. International Marketing Review, 25, 458-474.

70. Wong, A., \& Zhou, L. (2005). Consumers' motivations for consumption of foreign products: An empirical test in the People's Republic of China. Retrieved July 21, 2007, from: http:/www.u21global.com/PartnerAdmin/ ViewContent?module_DOCUMENTLIBRARY\&oid_14097

71. Yagci, M. I. (2001). Evaluating the effects of country-of-origin and consumer ethnocentrism: A case of a transplant product. Journal of International Consumer Marketing, 13(3), 63-85.

72. Zeugner-Roth, K. P., Žabkar, V., \& Diamantopoulos, A. (2015). Consumer ethnocentrism, national identity, and consumer cosmopolitanism as drivers of consumer behavior: a social identity theory perspective. Journal of International Marketing, (2), 25.

73. Zhou, L., Teng, L., \& Poon, P. (2008). Susceptibility to global consumer culture: A three-dimensional scale. Psychology \& Marketing, 25(4), 336-351.

74. Zhou, N., \& Belk, R. W. (2004). Chinese Consumer Readings Of Global And Local Advertising Appeals. Journal Of Advertising, 33(3), 63-76. 